\title{
Pelatihan Pengembangan Instrumen Penilaian KPS bagi Guru SMA Mapel Kimia di Kabupaten Sumenep
}

\author{
Muchlis, Rusmini dan Rusly Hidayah \\ Jurusan Kimia FMIPA Unesa, email: muchlis@unesa.ac.id
}

\begin{abstract}
Abstrak
Tujuan PKM ini adalah (1) mendeskripsikan pemahaman materi penilaian keterampilan proses sains peserta pelatihan, (2) mendeskripsikan kemampuan peserta pelatihan dalam mengembangkan instrumen penilaian keterampilan proses sains, dan (3) mendeskripsikan respon peserta pelatihan terhadap kegiatan pelatihan pengembangan instrumen penilaian keterampilan proses sains ini. Kegiatan pelatihan ini terdiri atas beberapa langkah: (1) Pembelajaran selama beberapa jam oleh tim PKM peserta pelatihan yaitu guru-guru Mapel Kimia SMA Kabupaten Sumenep dalam rangka penyegaran materi penilaian keterampilan proses sains, (2) Tim PKM memberikan tes pemahaman peserta terhadap materi pengembangan instrumen penilaian KPS, (3) Tim PKM memberi tugas peserta untuk mengembangkan instrumen penilaian KPS, dan (4) Tim PKM memberikan angket kepada peserta untuk mendapatkan data respon peserta terhadap pelaksanaan pelatihan pengembangan instrumen penilaian KPS. Instrumen dalam kegiatan pelatihan ini meliputi (1) Tes tulis untuk mengukur pemahaman peserta, (2) Lembar penilaian kemampuan peserta dalam mengembangkan instrumen penilaian KPS, dan (3) Angket untuk mengukur respon peserta. Kesimpulan dari kegiatan PKM ini adalah 1) Pemahaman materi pengembangan instrumen penilaian KPS peserta pelatihan dinyatakan tuntas secara klasikal dengan ketuntasan $85,7 \%$, 2) Ketujuh peserta pelatihan telah mengembangkan dengan baik instrumen penilaian KPS, dan 3) Peserta memberikan respon secara baik terhadap pelatihan pengembangan instrumen penilaian KPS.
\end{abstract}

Kata kunci: pelatihan, instrumen penilaian KPS.

\section{Abstract}

The objectives of this PKM are (1) to describe the understanding of the material for the assessment of the science process skills of the trainees, (2) to describe the ability of the trainees to develop a science process skills (SPC) assessment instrument, and (3) to describe the response of the trainees to the training activities for the development of this science process skills assessment instrument. This training activity consists of several steps: (1) Learning for several hours by the PKM team of training participants, namely teachers of Chemistry Mapel at SMA Sumenep Regency in order to refresh the science process skills assessment material, (2) The PKM team provides a test of participants' understanding of the development material. the PPP assessment instrument, (3) the PKM team assigns participants the task of developing the SPC assessment instrument, and (4) the PKM team provides a questionnaire to the participants to obtain data on participant responses to the implementation of the SPC assessment instrument development training. The instruments in this training activity include (1) a written test to measure participants' understanding, (2) an assessment sheet for the ability of participants to develop a PPP assessment instrument, and (3) a questionnaire to measure participant responses. The conclusions of this SPC activity are 1) The understanding of the material for developing the SPC assessment instrument for the trainees is declared classically complete with $85.7 \%$ completeness, 2) The seven training participants have developed the SPC assessment instrument well, and 3) Participants responded well to the training. development of SPC assessment instruments.

Keywords: Training, instrument of science process skills assessment.

\section{PENDAHULUAN}

Universitas Negeri Surabaya (Unesa) menyelenggarakan layanan pendidikan di semua tingkat pendidikan, yaitu pendidikan tinggi, sekolah menengah atas, sekolah menengah pertama, sekolah dasar, dan taman kanak-kanak sebagai wujud pelayanan pendidikan. Salah satu wujud nyata pelayanan pendidikan ini adalah kerjasama antara Jurusan Kimia FMIPA Unesa dengan guru-guru SMA yang tergabung dalam MGMP Kimia Kabupaten Sumenep. Ada sekitar
80 SMA negeri dan swasta di Kabupaten Sumenep. SMA di Kabupaten Sumenep telah menerapkan Kurikulum 2013.

Komponen terpenting implementasi kurikulum adalah pelaksanaan proses pembelajaran yang diselenggarakan di dalam dan/atau luar kelas untuk membantu peserta didik mencapai kompetensi sikap, pengetahuan dan keterampilan. Peraturan Menteri Pendidikan dan Kebudayaan nomor 65 tahun 2013 tentang Standar Proses menyatakan bahwa proses 
pembelajaran menggunakan pendekatan atau metode pembelajaran yang sesuai dengan karakteristik peserta didik dan mata pelajaran. Di antara pendekatan dan metode yang dianjurkan dalam Standar Proses tersebut adalah pendekatan saintifik, inkuiri, pembelajaran berbasis masalah dan pembelajaran berbasis projek pada semua mata pelajaran. Pendekatan/metode lainnya yang dapat diimplementasikan antara lain pembelajaran kontekstual dan pembelajaran kooperatif (Kemendikbud, 2014). Implementasi

Kurikulum 2013 berimplikasi pada model penilaian pencapaian kompetensi peserta didik. Penilaian adalah bagian integral dari pembelajaran (O'Farrell, 2009). Penilaian adalah suatu proses pengumpulan informasi, yang dalam konteks pengajaran, informasi ini digunakan untuk menguji dan menggambarkan prestasi peserta didik (Enger dan Yager, 2009). Penilaian juga berguna untuk mengidentifikasi kekuatan dan kelemahan siswa sehingga guru bisa mempersiapkan program akademik dan kegiatan sosial untuk pengembangannya (Yambi, 2018). Menurut Wijayanti (2014), penilaian berguna untuk mengetahui tingkat ketercapaian dari tujuan pembelajaran, melihat keefektifan proses belajar mengajar, dan seberapa besar tujuan dapat dicapai. Demikian pula Astuti, dkk (2012) mengemukakan bahwa penilaian berguna untuk mengukur tingkat ketercapaian dari indikator pembelajaran dan mengumpulkan informasi perkembangan belajar peserta didik pada berbagai aspek.

Sesuai dengan Peraturan Menteri Pendidikan dan Kebudayaan No. 66 Tahun 2013 tentang Standar Penilaian Pendidikan, penilaian pencapaian kompetensi pada jenjang pendidikan dasar dan menengah dilaksanakan oleh pendidik, satuan pendidikan, pemerintah dan/atau lembaga mandiri. Penilaian pencapaian kompetensi oleh pendidik dilakukan untuk memantau proses, kemajuan, dan perkembangan pencapaian kompetensi peserta didik sesuai dengan potensi yang dimiliki dan kemampuan yang diharapkan secara berkesinambungan. Penilaian juga dapat memberikan umpan balik kepada pendidik agar dapat menyempurnakan perencanaan dan proses pembelajaran.

Penilaian pencapaian kompetensi dilaksanakan dalam suasana yang menyenangkan, sehingga memungkinkan peserta didik menunjukkan apa yang dipahami dan mampu dikerjakannya. Pencapaian kompetensi seorang peserta didik dalam periode waktu tertentu dibandingkan dengan hasil yang dimiliki peserta didik tersebut sebelumnya dan tidak dianjurkan untuk dibandingkan dengan peserta didik lainnya. Dengan demikian peserta didik tidak merasa dihakimi oleh pendidik tetapi dibantu untuk mencapai kompetensi atau indikator yang diharapkan.

Mata pelajaran kimia adalah salah satu dari mata pelajaran yang juga harus dilakukan penilaian. Namun yang sering dilakukan adalah penilaian produk dan sikap ilmiah. Sementara mata pelajaran kimia merupakan bagian dari sains, dan hakikat sains mencakup tiga hal yaitu 1) produk ilmiah, 2) proses ilmiah dan 3) sikap ilmiah (Mariana dan Praginda, 2009). Produk ilmiah dapat berupa konsep, prinsip, hukum dan teori. Proses ilmiah mencakup perumusan masalah, perumusan hipotesis, pengumpulan data, menganalisis data dan menyimpulkan. Keterampilan melaksanakan proses sains ini biasa dikenal dengan istilah Keterampilan Proses Sains (KPS). Sikap ilmiah meliputi keteguhan hati, ketekunan, keingintahuan dan menyingkap rahasia alam. Dengan demikian penilaian mata pelajaran kimia seharusnya tidak hanya produk dan sikap ilmiah, tetapi juga KPSnya.

Keterampilan Proses Sains (KPS) adalah proses dalam melakukan aktivitas-aktivitas yang terkait dengan sains (Tawil \& Liliasari, 2014). Keterampilan proses sains merupakan segala kegiatan, yang dilakukan siswa dalam penyelidikan ilmiah untuk memungkinkan perolehan pengetahuan dan keterampilan ilmiah (Abungu, Okere, \& Wachanga, 2014). Sementara data hasil survei dari Programme for International Student Assesment (PISA) menunjukkan keterampilan berpikir siswa Indonesia masih tergolong rendah. Menurut Budiman dan Jailani (2014), salah satu penyebabnya adalah siswa di Indonesia kurang terlatih dalam menyelesaikan soal-soal yang mengukur keterampilan berpikir, dan masalah yang dihadapi oleh guru adalah kemampuan guru dalam mengembangkan instrumen asesmen tersebut masih kurang.

Penilaian KPS dapat terwujud jika guru sebagai pelaksana penilaian di kelas memiliki kemampuan mengukur KPS siswa. Pengukuran KPS memerlukan instrumen penilaian KPS. MGMP Mapel Kimia Kabupaten Sumenep tidak berjalan baik, sehingga pelatihan-pelatihan untuk menunjang terwujudnya pelaksanaan Kurikulum 2013 belum banyak diterima para guru kimia. Oleh karena itu pelatihan penyusunan instrumen penilaian KPS sangat diperlukan oleh para guru kimia di kabupaten Sumenep. Kegiatan PKM ini bertujuan untuk 1) memberikan pemahaman materi pengembangan instrumen penilaian KPS, 2) memberikan pelatihan dalam mengembangkan instrumen penilaian KPS, dan 3) menciptakan respon baik terhadap kegiatan pelatihan pengembangan instrumen penilaian KPS.

\section{METODE PELAKSANAAN}

Ada banyak guru kimia di kabupaten Sumenep yang tersebar di hampir 100 sekolah baik SMA Negeri maupun swasta. MGMP Kimia belum berjalan baik. Beberapa guru memang sudah pernah memperoleh pelatihan dalam implementasi kurikulum 2013, namun mayoritas belum pernah mendapatkan pelatihan penyusunan instrumen penilaian KPS.

Metode dalam pelatihan ini adalah metode ceramah, penugasan dan angket. Ceramah dimaksudkan untuk memberikan pemahaman materi KPS, dan bagaimana membuat instrumen penilaian KPS. Penugasan 
maksudnya memberi tugas kepada peserta untuk menyusun instrumen penilaian KPS. Pemberian angket dimaksudkan untuk mengetahui respon peserta atas pelatihan ini.

Teknik pengambilan data dilakukan melalui tes atas pemahamn materi KPS, penilaian terhadap instrumen penilaian KPS yang disusun peserta dan angket dalam rangka mengetahui respon peserta terhadap pelatihan ini. Khusus penilaian terhadap instrumen penilaian KPS yang disusun peserta, diberi waktu 2 minggu setelah pelatihan untuk memberi kesempatan peserta pelathian menyusun instrumen penilaian KPS. Sementara tes dan angket dilakukan pada hari pelaksanaan pelatihan.

Pelaksanaan kegiatan pelatihan ini terdir atas beberapa langkah yaitu 1) pembelajaran selama beberapa jam oleh tim PKM kepada peserta pelatihan yaitu guru-guru SMA Mapel Kimia Kabupaten Sumenep dalam rangka penyegaran materi pengembangan instrumen penilaian KPS, 2) tim PKM menilai instrumen penilaian KPS yang dikembangkan peserta pelatihan, 3) tim PKM memberikan angket kepada peserta untuk mendapatkan data respon peserta terhadap pelaksanaan pelatihan pengembangan instrumen penilaian KPS.

Bahan-bahan yang diperlukan dalam pelaksanaan pelatihan ini mencakup 1) Slide berisi materi tentang KPS, dan 2) Materi pelatihan, Adapun alat yang diperlukan mencakup 1) kamera, dan 2) slide proyektor.
Instrumen dalam kegiatan pelatihan ini meliputi 1) tes tulis digunakan untuk mengukur pemahaman peserta tentang pengembangan instrumen penilaian KPS, 2) lembar penilaian untuk mengukur kemampuan peserta mengembangkan instrumen penilaian KPS, 3) angket untuk mengukur respon peserta terhadap pelaksanaan pelatihan pengembangan instrumen penilaian KPS. berikut.

Data yang diperoleh dianalisis sebagai

1. Data pemahaman peserta setelah pembelajaran dalam rangka penyegaran materi pengembangan instrumen penilaian KPS dinyatakan sebagai berikut: Skor diperoleh

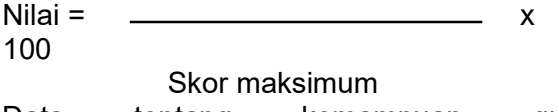

2. Data tentang kemampuan guru mengembangkan instrumen penilaian KPS dinyatakan sebagai berikut:

Skor diperoleh

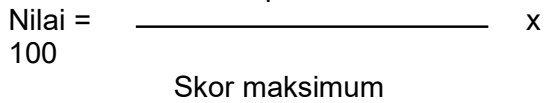

3. Data tentang respon peserta terhadap pelaksanaan pelatihan pengembangan instrumen penilaian KPS dinyatakan dalam persentase. Pemaknaan besarnya persentase tiap item mengacu pada Tabel 1.

Tabel 1 Pemaknaan Persentase Kemampuan dan Respon Peserta Pelatihan

\begin{tabular}{|c|c|}
\hline Persentase & Keterangan \\
\hline $0-20$ & Sangat Buruk \\
\hline $21-40$ & Buruk \\
\hline $41-60$ & Cukup \\
\hline $61-80$ & Baik \\
\hline $81-100$ & Sangat Baik \\
\hline
\end{tabular}

(adaptasi dari Riduwan, 2011)

HASIL DAN PEMBAHASAN

\section{Pemahaman Peserta terhadap Materi}

Pengembangan Instrumen Penilaian KPS

Selama beberapa jam, tim PKM memberikan materi pelatihan pengembangan instrumen pengembangan penilaian KPS. Foto kegiatan ini tampak pada Gambar 1. Tim PKM dan peserta antusias dalam kegiatan pemaparan materi pelatihan sebagaimana terlihat pada Gambar 1. Pemaparan materi KPS mencakup, pengertian, jenis-jenis KPS, landasan teoritis, manfaat, contoh-contoh instrumen penilaian KPS termasuk rubrik penilaiannya. Ada kegiatan tanya jawab dalam sesi pemaparan ini, terutama para peserta minta contoh instrumen penilaian KPS untuk jenis KPS tertentu. Setiap anggota tim PKM aktif mengambil peran dalam sesi pemaparan ini.

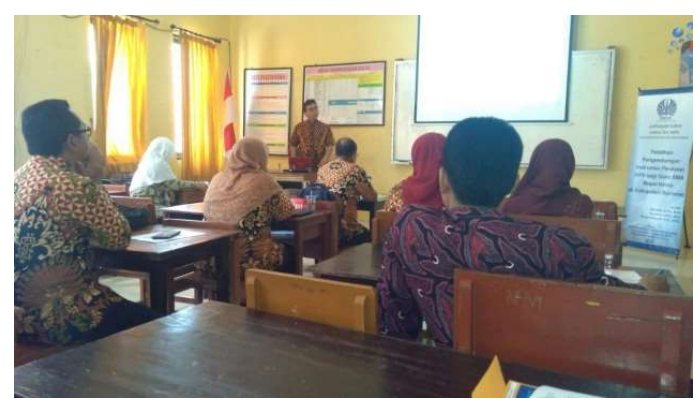

Gambar 1 Tim PKM memberikan materi pelatihan 
Pengukuran pemahaman peserta pelatihan terhadap materi pelatihan dilaksanakan pada akhir sesi tatap muka menggunakan Tes Tulis. Tampak pada Gambar 2, peserta penuh konsentrasi mengerjakan tes tulis. Semua peserta mengerjakan dengan baik, tanpa mencontoh temannya. Tes ini dikondisikan para peserta mengerjakan tanpa melihat catatan sendiri atau mencontek makalah materi KPS. Para peserta menyelesaikan tes ini tepat waktu.

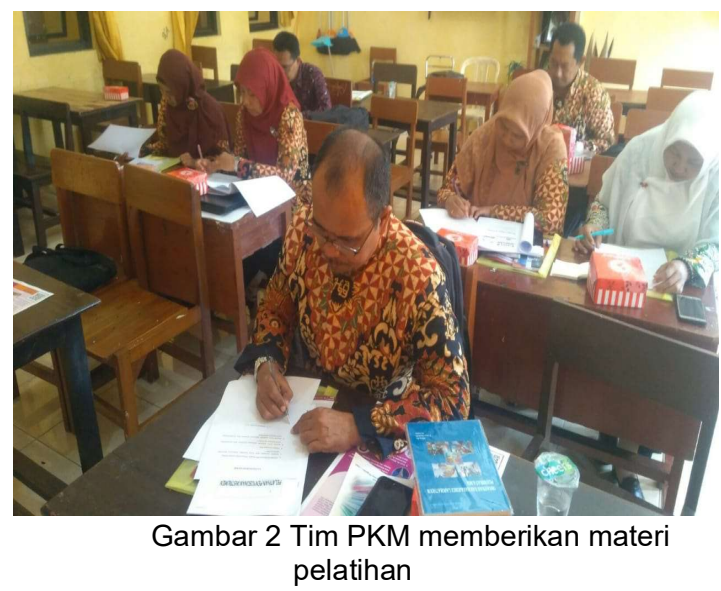

Hasil tes pemahaman terhadap materi KPS selanjutnya dianalisis. Batas nilai ketuntasan individu adalah 75. Rekap hasil analisis tertulis tertera dalam Tabel 2. Berdasarkan Tabel 2 terlihat bahwa ketuntasan klasikal sebesar $85,7 \%$. Persentase ketuntasan klasikal pemahaman materi peserta ini sudah lebih dari $75 \%$ sehingga dikatakan target/tujuan telah tercapai.

Gambar 3 merupakan grafik perolehan nilai para peserta pelatihan pengembangan instrumen penilaian KPS. Hanya satu yaitu DYH yang tidak tuntas dari 7 peserta pelatihan. DYH kurang sempurna dalam mendefinisikan pengertian KPS dengan menggunakan kata-kata sendiri.

Tabel 2 Nilai peserta pelatihan terhadap materi pelatihan pengembangan instrumen KPS

\begin{tabular}{|c|l|c|c|}
\hline No. & Nama Peserta & Nilai & Ketuntasan \\
\hline 1 & SRD & 85 & Tuntas \\
\hline 2 & SFH & 80 & Tuntas \\
\hline 3 & IR & 80 & Tuntas \\
\hline 4 & MW & 80 & Tuntas \\
\hline 5 & ITQ & 80 & Tuntas \\
\hline 6 & DYH & 70 & Tidak Tuntas \\
\hline 7 & BUM & 90 & Tuntas \\
\hline \multicolumn{2}{|r|}{} \\
\hline
\end{tabular}

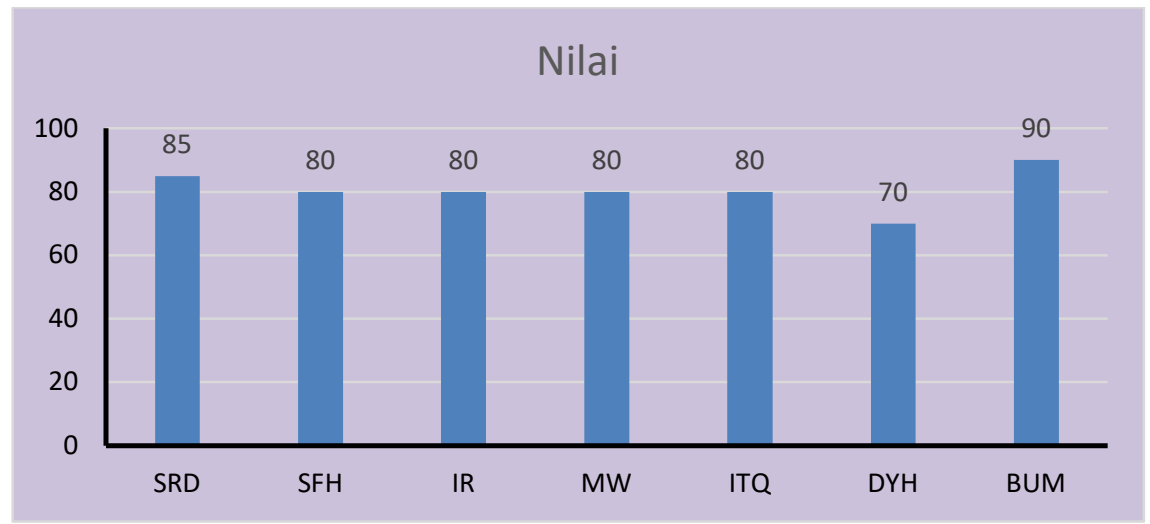

Gambar 3 Grafik nilai yang diperoleh peserta pelatihan

Instrumen Penilaian KPS yang Dikembangkan Peserta

Setiap peserta pelatihan diberikan tugas mengembangkan instrumen penilaian KPS dalam waktu 2 minggu setelah kegiatan tatap muka. Dua peserta mengembangkan penilaian KPS untuk materi di kelas $X$, tiga peserta mengembangkan penilaian KPS untuk materi di kelas XI dan dua peserta mengembangkan penilaian KPS untuk materi di kelas XII.

Tujuh peserta pelatihan berhasil mengembangkan instrumen penilaian KPS. Hasil Penilaian instrumen penilaian KPS yang dikembangkan terangkum dalam Tabel 3 . Berdasarkan Tabel 3 tampak bahwa peserta pelatihan telah tuntas $100 \%$ dalam menyelesaikan 
tugas mereka menyusun instrumen KPS. Ini menandakan keberhasilan kegiatan PKM dalam melatih guru-guru kimia di Kabupaten Sumenep dalam menyusun instrumen penilaian KPS.

Meskipun DYH tidak tuntas dalam uji pemahaman materi KPS, namun kemampuannya mengembangkan instrumen penilaian KPS telah mencapai ketuntasan. Artinya tujuan atau target melatih guru-guru mengembangkan instrumen penilaian KPS telah tercapai 100\%. Dengan

demikian, amanah kurikulum 2013 agar siswa memiliki KPS dapat dilaksanakan oleh guru-guru kimia di Kabupaten Sumenep. Guru tidak lagi khawatir melatihkan KPS kepada siswanya karena telah mampu mengembangkan instrumen penilaian KPS untuk mengukur KPS siswanya.

Tabel 3 Rangkuman hasil penilaian instrumen penilaian KPS Mapel Kimia yang dikembangkan peserta

\begin{tabular}{|c|c|c|c|c|c|c|}
\hline No. & $\begin{array}{c}\text { Nama } \\
\text { Peserta }\end{array}$ & Topik & kelas & Asal Sekolah & Nilai & $\begin{array}{l}\text { Ketuntas } \\
\text { an }\end{array}$ \\
\hline 1 & SRD & $\begin{array}{l}\text { Hukum Dasar } \\
\text { Kimia }\end{array}$ & $\mathrm{X}$ & $\begin{array}{l}\text { SMA PLUS MIFTAHUL ULUM } \\
\text { SUMENEP }\end{array}$ & 75 & Tuntas \\
\hline 2 & SFH & $\begin{array}{l}\text { Larutan Asam } \\
\text { Basa }\end{array}$ & XI & $\begin{array}{l}\text { SMA NAHDLATUL ULAMA } \\
\text { SUMENEP }\end{array}$ & 83 & Tuntas \\
\hline 3 & IR & $\begin{array}{l}\text { Hakekat Ilmu } \\
\text { Kimia/Metode } \\
\text { Ilmiah }\end{array}$ & $\mathrm{X}$ & SMAN 1 BLUTO SUMENEP & 83 & Tuntas \\
\hline 4 & MW & Termokimia & $\mathrm{XI}$ & SMAN 1 SUMENEP & 92 & Tuntas \\
\hline 5 & ITQ & $\begin{array}{l}\text { Penurunan Titik } \\
\text { Beku Larutan }\end{array}$ & XII & $\begin{array}{lll}\text { SMAN } & 1 & \text { AMBUNTEN } \\
\text { SUMENEP } & & \\
\end{array}$ & 75 & Tuntas \\
\hline 6 & $\mathrm{DYH}$ & Korosi Besi & XII & SMAN 2 SUMENEP & 75 & Tuntas \\
\hline 7 & BUM & Laju Reaksi & $\mathrm{XI}$ & SMA 3 ANNUQYAH SUMENEP & 92 & Tuntas \\
\hline & & & & Ketuntasan Klasikal & \multicolumn{2}{|c|}{$100 \%$} \\
\hline
\end{tabular}

Respon Peserta Pelatihan Pengembangan Instrumen Penilaian KPS terhadap Pelaksanaan Pelatihan

Setelah sesi tatap muka pelatihan, peserta diberi angket respon. Hasilnya tertulis dalam Tabel 4. Persentase untuk respon positif dari kedelapan butir angket lebih dari $61 \%$.
Dengan demikian pelatihan pengembangan instrumen penilaian KPS mendapatkan respon baik dari peserta.

Tabel 4 Persentase respon peserta terhadap pelatihan pengembangan instrumen KPS

\begin{tabular}{|c|c|c|c|c|}
\hline No. & Butir Angket & \multicolumn{3}{|c|}{ Respon Peserta } \\
\hline \multirow[t]{2}{*}{1} & Menurut Anda materi pelatihan ini & menarik & $\begin{array}{l}\text { Kurang } \\
\text { menarik }\end{array}$ & $\begin{array}{l}\text { Tidak } \\
\text { menarik }\end{array}$ \\
\hline & & $100 \%$ & $0 \%$ & $0 \%$ \\
\hline \multirow[t]{2}{*}{2} & $\begin{array}{l}\text { Kompetensi narasumber terhadap materi yang } \\
\text { menjadi tanggungjawabnya }\end{array}$ & memadai & $\begin{array}{l}\text { Cukup } \\
\text { memadai }\end{array}$ & $\begin{array}{l}\text { Kurang } \\
\text { memadai }\end{array}$ \\
\hline & & $71,4 \%$ & $28,6 \%$ & $0 \%$ \\
\hline \multirow[t]{2}{*}{3} & Penyampaian materi pelatihan oleh narasumber & $\begin{array}{l}\text { Efektif dan } \\
\text { menarik }\end{array}$ & $\begin{array}{l}\text { Kurang } \\
\text { efektif dan } \\
\text { menarik }\end{array}$ & $\begin{array}{l}\text { Tidak } \\
\text { efektif dan } \\
\text { menarik }\end{array}$ \\
\hline & & $100 \%$ & $0 \%$ & $0 \%$ \\
\hline \multirow[t]{2}{*}{4} & $\begin{array}{l}\text { Pengembangan instrumen penilaian KPS dapat } \\
\text { diterapkan pada semua materi pokok mapel kimia }\end{array}$ & $\mathrm{Ya}$ & beberapa & $\begin{array}{l}\text { Tidak } \\
\text { dapat }\end{array}$ \\
\hline & & $57,1 \%$ & $42,9 \%$ & $0 \%$ \\
\hline \multirow[t]{2}{*}{5} & $\begin{array}{l}\text { Sulit mengembangkan instrumen penilaian KPS pada } \\
\text { proses belajar mengajar }\end{array}$ & mudah & sedang & sulit \\
\hline & & $57,1 \%$ & $42,9 \%$ & $0 \%$ \\
\hline \multirow[t]{2}{*}{6} & $\begin{array}{l}\text { Pelatihan pengembangan instrumen penilaian KPS } \\
\text { bermanfaat pada tugas mengajar guru dan sesuai } \\
\text { dengan kurikulum sekolah }\end{array}$ & $\mathrm{Ya}$ & $\begin{array}{l}\text { Kurang } \\
\text { bermanfaat }\end{array}$ & $\begin{array}{l}\text { Tidak } \\
\text { bermanfaat }\end{array}$ \\
\hline & & $100 \%$ & $0 \%$ & $0 \%$ \\
\hline \multirow[t]{2}{*}{7} & $\begin{array}{l}\text { Apakah KPS penting dilatihkan kepada siswa dalam } \\
\text { kegiatan pembelajaran? }\end{array}$ & $\mathrm{Ya}$ & $\begin{array}{l}\text { Cukup } \\
\text { penting }\end{array}$ & $\begin{array}{l}\text { Tidak } \\
\text { penting }\end{array}$ \\
\hline & & $71,4 \%$ & $14,3 \%$ & \\
\hline \multirow[t]{2}{*}{8} & $\begin{array}{l}\text { Menularkan hasil pelatihan ini kepada rekan kerja } \\
\text { saya }\end{array}$ & tidak & Pasti & $\begin{array}{l}\text { Lihat } \\
\text { kondisi }\end{array}$ \\
\hline & & $0 \%$ & $100 \%$ & $0 \%$ \\
\hline
\end{tabular}


Tabel 4 menginformasikan bahwa seluruh peserta setuju jika pelatihan ini merupakan kegiatan yang menarik, narasumbernya menyampaikan materi dengan efektif dan menarik, pelatihan pengembangan penilaian KPS ini membantu tugas guru dalam mengajar dan pasti guru-guru ini menularkan hasil pelatihan ini kepada guru-guru lain di sekolah masing-masing. Secara keseluruhan item respon memperoleh persentase lebih dari $61 \%$ sehingga dapat disimpulkan bahwa respon peserta adalah baik terhadap pelatihan pengembangan instrumen penilaian KPS ini.

\section{KESIMPULAN DAN SARAN \\ Kesimpulan}

Berdasarkan pembahasan dapat disimpulkan bahwa 1) pemahaman materi pengembangan instrumen penilaian KPS peserta pelatihan dinyatakan tuntas secara klasikal dengan ketuntasan $85,7 \%$, 2) ketujuh peserta pelatihan telah mengembangkan dengan baik instrumen penilaian KPS untuk satu topik pembahasan kelas X, XI dan XII mapel kimia, dan 3) peserta memberikan respon positif terhadap pelatihan pengembangan instrumen penilaian KPS.

Saran

Beberapa hal yang bisa disarankan adalah 1) tugas pengembangan instrumen penilaian KPS terkait jumlah KPS-nya diperbanyak, 2) perlu pendampingan di kelaskelas dalam rangka penerapan KPS dalam pembelajaran.

\section{DAFTAR PUSTAKA}

Abungu, H.E., Okere, M.I.O, dan Wachanga, S.W. 2014. The Effect of Science Process Skills Teaching Approach on Secondary School Students' Achievement in

Astuti, W. P., Prasetyo, A. P. B. dan Rahayu, E. S. 2012. Pengembangan Instrumen Asesmen Autentik Berbasis Literasi Sains pada Materi Sistem Ekskresi. Lembaran IImu Kependidikan, 41(1), 3943.

Budiman, Agus dan Jailani, Jailani. 2014. Pengembangan Instrumen Asesmen Higher Order Thinking Skill (HOTs) pada Mata Pelajaran Matematika SMP Kelas VIII Semester 1. Jurnal Riset Pendidikan Matematika, 1(2), 139-151

Enger, Sandra K dan Yager, Robert E. 2009. Assessing Student Understanding in Science. Thousand Oaks, CA, Corwin Press.

Kemendikbud, 2014, Panduan Penguatan Proses Pembelajaran Sekolah Menengah Pertama.
Mariana, I Made Alit dan Praginda, Wandy. 2009 Hakikat IPA dan Pembelajaran IPA. Jakarta: PPPP TK Diknas.

O'Farrell, Ciara. 2009. Enhancing Student Learning Through assessment. Diakses tanggal 27 April 2017 dari http://www.tcd.ie/teachinglearning/academicdevelopment/assets/pdf/250309 assess ment toolkit.pdf

Peraturan Pemerintah Republik Indonesia Nomor 32 Tahun 2013 tentang Perubahan atas Peraturan Pemerintah Nomor 19 Tahun 2005 tentang Standar Nasional Pendidikan.

Peraturan Menteri Pendidikan dan Kebudayaan Republik IndonesiaNomor 54 Tahun 2013 tentang Standar Kompetensi Lulusan Pendidikan Dasar dan Menengah.

Peraturan Menteri Pendidikan dan Kebudayaan Republik Indonesia Nomor 64 Tahun 2013 tentang Standar Isi.

Peraturan Menteri Pendidikan dan Kebudayaan Republik IndonesiaNomor 65 Tahun 2013 tentang Standar Proses.

Peraturan Menteri Pendidikan dan Kebudayaan Republik IndonesiaNomor 66 Tahun 2013 tentang Standar Penilaian Pendidikan.

Riduwan, 2011. Skala Pengukuran VariabelVariabel Penelitian. Bandung: Alfabeta

Tawil, Muh. \& Liliasari. 2014. KeterampilanKeterampilan Sains dan Implementasinya Dalam Pembelajaran IPA. Makassar: Badan Penerbit UNM.

Undang-Undang Nomor 20 Tahun 2003 tentang Sistem Pendidikan Nasional.

Wijayanti, A. 2014. Pengembangan Autentic Assessment Berbasis Proyek dengan Pendekatan Saintifik Untuk Meningkatkan Keterampilan Berpikir IImiah Mahapeserta didik. Jurnal Pendidikan IPA Indonesia, 3(2): 102-108. 